\title{
A Discovery of Multiple Levels of Open Innovation in Understanding the Economic Sustainability. A Case Study in the Manufacturing Industry
}

\author{
Alireza Javanmardi Kashan ${ }^{1}$, Kavoos Mohannak ${ }^{1}$, Mirko Perano ${ }^{2, *(1)}$ and Gian Luca Casali ${ }^{1}$ \\ 1 School of Management, Queensland University of Technology, Brisbane City QLD 4000, Australia; \\ ali.javanmardikashan@qut.edu.au (A.J.K.); k.mohannak@qut.edu.au (K.M.); luca.casali@qut.edu.au (G.L.C.) \\ 2 Department of Management, Reald University College, 9400 Vlorë, Albania \\ * Correspondence: mperano@unisa.it
}

Received: 6 September 2018; Accepted: 5 December 2018; Published: 6 December 2018

check for updates

\begin{abstract}
The aim of this paper is twofold: firstly, investigate the theory of governance and open innovation by adding the process of value creation and value capture; secondly, to discuss the potential link between open innovation and economic sustainability. With the current emphasis of the literature being on either the value creation or value capture processes, the phenomenon of open innovation is only partially understood. To help broaden this understanding, we conducted an in-depth case study of the processes behind the transformation of governance structures at Iran Khodro Company (IKCO), which led to the emergence of both value creation and capture processes. A multi project analysis (from 1994 to 2012) has point out that IKCO have created and developed a formal value creation and capture processes from the part level through to the architectural level, allowing a gradual openness at those levels and at the same time ensuring a greater economic sustainability of the IKCO business. These findings reveal the existence of four unique levels of open innovation in product development architecture. Practical implications are also provided relating the impact that each of these levels can have on the economic sustainable model of the firms in the manufacturing sector.
\end{abstract}

Keywords: open innovation; governance; transformation; value creation; value capture; economic sustainability; product development

\section{Introduction}

After a long tradition assuming that the environment and industry positioning or a firm's specific resources as the sources of competitive advantage, a new paradigm in strategy is emerging. This new paradigm is based on the interfaces between the firm and its environment oriented toward a sustainable business. In this regard, the leading concept is open innovation, which also represents an increasing trend within firms of moving away from relatively "closed" innovation strategies toward "open" innovation processes. Chesbrough and Appleyard [1] provided the foundations for combining an open innovation and sustainable business model as part of what they called an "open strategy" (p. 58). The view of a sustainable business model is based on strategically creating value by balancing firm's openness to innovation processes. The authors point out the experiments made by firms and whole industries aimed at identifying "novel business model based on harnessing collective creativity trough open innovation"; so, "many of these experimenters now are grappling with issues related to value capture and sustainability of their business models, as well as issues of corporate influence and the potential co-option of open initiatives" [1] (p. 57). Between innovation and competitive advantage, there is a complex and multidimensional relationship [2], in which sustainability plays a primary role. 
Therefore, the "innovation must be characterized by sustainability" [3] (p. 8). Elkingdon [4] provides a definition of sustainability as a balance of a triple bottom line of economic, social, and ecological goals. Lopes et al. [5] support the merging between open innovation and sustainability: "through OI, companies can leverage knowledge management to an asset that promotes sustainable innovation in terms of a social, environmental (or ecological) and economic point of view" (p. 476). However, for the purpose of this paper we will concentrate on discussing the potential relationship between economic sustainability and Open Innovation (OI).

According to [6,7] "an economically sustainable company guarantees sufficient cashflow to ensure liquidity at any time, while producing a persistent above-average return to its shareholders" [7] (p. 3). Therefore, a sustainable business can be defined as "the ability of firms to respond to their short-term financial needs without compromising their (or others') ability to meet their future needs" [8] (p. 71). In other words, economic sustainability can be referred to the capacity of the firm to be profitable not only today but also tomorrow.

The open innovation literature has emphasized such openness in terms of either acquiring external technological knowledge or commercializing internal technological knowledge. Inbound open innovation is an outside-in process and it involves opening up the innovation process to knowledge exploration. In the context of new product, the inbound aspect of open innovation plays an important role [9] in achieving sustainable advantage and viability overtime [10-12]. In contrast, outbound open innovation is an inside-out process and it includes opening up the innovation process to knowledge exploitation. The outbound open innovation approach can be used to achieve a specific competitive strategy, especially in terms of cost leadership [13] by obtaining a lower cost of products/components from their suppliers. More in detail, this relationship provides a win-win scenario: on one side, the firm obtains an economic advantage that can ultimately enhance the economic sustainability of the project (or create the conditions to reduce a cost misalignments); and, on the other side, the supplier can improve its opportunity to expand its market capitalizing on the newly gained capabilities (as a results of the knowledge sharing as part of the open innovation process) to better satisfy others potential clients' needs.

Nevertheless, firms more and more combine outside-in and inside-out processes, integrating inbound and outbound open innovation (e.g., in alliances; see [14]). Despite the recent emphasis within the literature on integrating these two sides of open innovation to both create and capture value, empirical research so far has focused either on inbound or outbound open innovation by relying solely on governance theories or the resource- and capability-based views as the theoretical lens. This oversight leads to some contradictions in the open innovation literature, such as the contrasting logics of open innovation versus open sourcing.

We propose to integrate both theoretical lenses and enhance our understanding of coupled open innovation processes to overcome this problem. In this regard, we aim to deepen our understanding of the governance approach to open innovation by adding process insights. Therefore, this study is designed to find the mechanism behind the coupled open innovation processes also while using a sustainability view. Specifically, we examined the transformation of governance structures at Iran Khodro Company (IKCO), which led to the emergence of value creation and value capture processes. This case has been selected as an extreme case, while considering the period of capability development during which open innovation processes unfolded.

IKCO experienced a period of capability development, transforming from a car-assembler to a leading carmaker that is capable of both value creation and capture. Particular emphasis was placed on the processes at the micro-level, as a way to achieved desired outcomes (i.e., coupled open innovation) at the organizational level. Subsequently, we focused on four product innovation projects in which (during the life cycle of each project) the required capabilities for open innovation at IKCO were developed.

Such a move toward openness occurred due to IKCO's central role in the government's economic liberalization policies, especially those in relation to the auto industry, as Iran's second most strategic 
industry. In addition, we have strived to reveal the underlying mechanisms enabling the unfolding of coupled open innovation activities by undertaking an in-depth study of four product innovation projects as the major steps to achieve openness in the case company.

\section{Theoretical Background and Research Question}

The concept of open innovation is neither new nor generalized across industries, academic views, and firms' practice. For example, open innovation has been seen with a numbers of growth limitations of capitalism under the Schumpeterian view [15]. A way to minimize these limits of open innovation is by encouraging the adoption and combinations of new business models and technologies [16] merged with multiple dynamic capabilities [17] at the micro-level for emergent firms. Organizational success has been linked to the development of competitive advantage, which is the result of a strategic combination between dynamic capabilities of strategic management $[18,19]$ in within dynamic market. By linking open connections with new technologies in the market it is possible to capture "a new kind of Schumpeterian combination [ ... ], which means a kind of open innovation model" [19] [16,20] that can include the characteristics of the evolutionary change (e.g., economic, environmental, social, technological). Therefore, there is an ongoing need to continuously work to facilitate the creation of knowledge and innovation at the micro level. Chesbrough [21] describes the need for open innovation based on the limitations of internal resources and opening up the firm's boundaries to external sources. He further mentioned that "Firms can and should use external ideas as well as internal ideas, and internal and external paths to market, as the firms look to advance their technology" [21] (p. xxiv). As a result of such a new view of the potential sources of innovation, there is an increasing number of scholars who characterize the open innovation concept as starting a major paradigm shift. In this regard, Chesbrough and Appleyard [1] pointed to the emerging empirical cases through which the pillars of the five competitive forces of Porter (through which a competitive advantage is built) are revalued. Based on Porter's framework, intensive competition reduces industry profits; however, we can see highly profitable organizations (e.g., Google and Yahoo), which exist in the presence of such competition.

Despite the need for a responsive theory of open innovation and the emerging evidence of the effectiveness of external sources for problem identification and solution [22-26], we are increasingly observing firms that initiate open innovation to engage external contributors in the hope of improving performance often fail [27-29]. The underpinning theory of open innovation has not been fully uncovered to explain all of the required elements, which make open innovation a successful practice. West et al. [30] argued that research on open innovation is still at the stage of finding the most relevant theoretical roots.

Among the alternative explanatory lenses, the resource-based view and governance theories are perhaps the most relevant ones, as they have demonstrated strong links to open innovation since their initial articulation. In particular, those studies that are based on governance theories dealing with dynamics of governance in the context of open innovation are most relevant. For example, Gambardella and Panico [31] have suggested a framework supporting firms on "how" to allocate property rights and decision rights that is based on the distinction between the allocation of decision rights during a project and control rights to maximize the actual output of open innovation collaboration. Felin and Zenger [29] developed a conceptual model that is based on traditional hierarchy vs. market distinction, forming six governance shapes, and suggesting that the choice of governance shape depends on the nature of the knowledge required and the nature of the problem that they deal with. By this way, Chesbrough and Appleyard starting from the business strategies for open initiatives, detect "a number of emerging business models attempt to balance the benefits of openness with the need for some value capture for greater sustainability" [1] (p. 71). Clearly, this stream of research has so far focused on the nature of open innovation activities (through the lens of governance dynamics) and the contingents, which justify the open innovation core processes. We believe that findings from these studies help to uncover the content of open innovation. 
Similarly, the resource and capability-based views seem to have strong potential for understanding the phenomenon of open innovation, with prior efforts in the area of dynamic capability providing some initial insights in this direction. For example, Teece [32] underline the open innovation in discussing about the dynamic capabilities that allow firms to "sense" and "seize" opportunities, and point out the quality of the relationship between open innovation and research on absorptive capacity [33,34]. Aligned with this stream of research, Lichtenthaler and Lichtenthaler [35] pursued the development of the resource and capability-based views of open innovation. Based on this view, open innovation is basically seen as a context where firms can manage their knowledge base evolution through knowledge exploration and exploitation processes. Accordingly, the capability-based view of open innovation is built on the basic assumptions and suggestions of evolutionary theory. According to this theory, the existing failure of open innovation in performance improvement that is shown in some studies could be attributed to the lack of required resources and capabilities [36]. In this regard, Gassmann and Enkel [37] point out the need of specific capabilities form the firms to adopt the open innovation approach. This last can be effectively if these capabilities are address to apply the open innovation both outside the organization that inside through different forms of cooperation; each specific process require specific capability. In order to reach more effectively, the absorptive capability need to be complemented with other capabilities: multiplicative and relational. We argue that such capabilities would help to uncover the process of open innovation.

As previously discussed in the literature, open innovation currently uses multiple theoretical lenses separately. Therefore, those studies using a governance lens mostly lack process insight and those applying the resource and capability-based views lack content insights. Consequently, we argue that to strengthen the existing theory based of open innovation we need to develop complementary insights for each of these theoretical lenses.

In this study, we aim to contribute to the governance view and provide additional insights from the process aspects behind the emergence of governance structures. Here, the aspect of open innovation process [38] is related to the evolution from closed to open innovation and to the steps necessary for each firm that want to open up its own innovation process. For example, Gassman et al. [14] found that open innovation normally begins with outsourcing to external contractors and it then progresses towards deeper types of open innovation, while Chiaroni et al. [39] identified some of the organizational factors, processes, and systems that facilitate transition from closed to open innovation. In addition, Chiaroni et al. [40] applied Lewin's model of organizational change [41] with three stages: unfreezing, moving, and institutionalizing. However, there have been fewer studies on process as the "unfolding of a central phenomenon"; defined by Van de Ven [42] as a study that "takes an historical development perspective, and focuses on the sequences of incidents, activities, and stages that unfold over the duration of a central subject's existence" (p. 170).

As such, despite the emphasis of some scholars, such as West et al. [30], on undertaking more quantitative studies on open innovation, we believe that qualitative studies are still so critical in revealing the underlying process. This view is aligned with Huizingh [43], who argued that case studies are useful not only for understanding how things works and identifying the important concepts, practices and contexts, but that they can also be used for elaboration purposes in open innovation research in developing measures and recognizing testable relationships.

Around the open innovation context, in this research we concentrate the efforts to better understand the open innovation process and inside this last, the processes underlying the transformation of governance structures. To conduct such a case study, we had to clarify the research context. In this regard, three different types of open innovation are available. Gassmann and Enkel [37] refer to these different types of open innovation as: inbound, outbound, and coupled open innovation. Inbound open innovation can be defined as an outside-in process that involves opening up the innovation process to knowledge exploration. Here, external knowledge exploration refers to the acquisition of knowledge from external sources. In contrast, outbound open innovation relates to commercializing technological knowledge [37]. Michelino et al. [44] report that "it follows that inbound 
activities are generally more frequent than outbound ones" (p. 67). In contrast to these, coupled open innovation involves both inbound and outbound open innovation. Chesbrough [45] argued that both inbound and outbound open innovation processes are required, as the value that is created through inbound open innovation processes should be appropriated within the outbound open innovation processes. This highlights the larger importance of understanding coupled open innovation, as we can then better understand simultaneously both value creation and capture [46,47]. The existing emphasis of the open innovation literature on one side of open innovation-being either value creation or value capture-has led to some contradictory research results, suggesting two distinct appropriability approaches in innovation to achieve the same goal of profiting from innovation.

Discussions emphasizing the value creation role of open innovation follow Von Hippel's [24] principals of democratizing innovation, which are completely against establishing intellectual property (IP) protection or any other kind of appropriability regimes to enhance innovation by facilitating "free reveal" of a firm's achievements to others [48-51]. On the other hand, arguments that are concerned with value capture in open innovation are rooted in Teece [52], who stressed that, to gain profit out of innovation, an innovator should be able to either vertically integrate or contract for services without leakage to rivals (see also $[53,54]$ ). Studies following this tradition have associated outbound open innovation with the threat of knowledge hollowing-out [55]. As such, they suggest forming outbound open innovation processes based on out-licensing patented IP and strong appropriability (see for example [56-59]).

As a result of such contradiction, some scholars have differentiated "open innovation" from "open sourcing" $[30,43,45]$. In the current literature, it has been strongly argued the ongoing necessity for moving towards a more open approach to innovation. However, what is not so clear is how to accommodate the transition between the two seemingly opposing views (open and close) in the "overall picture" of open innovation to develop a better understanding of the concept of coupled open innovation. Therefore, we chose coupled open innovation as the context for our study in order to learn about the underlying processes behind the transformation of governance structures, which leads to the emergence of value creation and value capture processes in firms. Accordingly, the research question of this study is formed as:

What is the process behind the emergence of value creation and capture processes in the context of coupled open innovation?

With our specific focus on the "coupled" open innovation processes, which combine both inbound and outbound flows (see also $[48,53,55]$ ), we had to shift beyond the dyadic interaction between two firms to collaborations with external networks, ecosystems, and communities [58,60,61]. In particular, we included local suppliers in our research. Gassmann et al. [14] argued that, despite the fact that suppliers' early integration into the innovation process can considerably enhance innovation performance in different industries [62,63], the downstream side of innovation has been less subject to analysis. We also took the advice of West et al. [30] in extending the levels of analysis and included the project level, firm level, and business ecosystem level in our analysis of open innovation (cfr. [58,64]). Aligned with Vanhaverbeke et al. [65], we applied open innovation to a new context (a non-Western firm) in pursuing the challenges that managers face in organizing for open innovation.

\section{Research Method and Analysis}

As previously mentioned, this study examines the dynamics of governance approaches in the context of coupled open innovation. In particular, the research aims to better understand the processes that are involved in building value creation and value capture processes and the emergence of coupled open innovation within firms. Therefore, the objective of this study is to "understand complex process issues" [66] and takes an approach similar to a practice approach, where the focus is on micro-processes as a central locus of organizing and the main driver of producing, reinforcing, and changing organizational consequences [67]. Broadly, this study fits with what we attribute as process research $[68,69]$. Aligned with this approach, we chose the (single) case study method $[70,71]$ using 
a multi-project approach as the research strategy. It is appropriate for examining complex social phenomena, allowing for the researcher to grasp a holistic understanding of real-life events [72], reveal the underlying processes, including multiple casual chains [73] and governance processes [74], and allow for approaching all the elements of social system as a whole [75]. While this study is essentially theory elaboration (as the constructs already exist in the literature), it simultaneously consists of some pure induction on the nature of these constructs and the underlying mechanism that builds their higher-order relationships. In this sense, the approach that was taken in this research has similarities with the extended theory approach suggested by Burawoy [76].

\subsection{Research Context}

The focus of this research on both processes as well as organizational outcomes, as the objectives of analysis, necessitates rich information from the field accompanied by deep analysis. As a result, we chose to conduct our case study within a single organization: Iran Khodro Company (IKCO). In the context of the Iranian auto industry, IKCO constitutes an extreme case [70], which was particularly useful for our research question, being an exemplar of a context for the development of coupled open innovation activities. By definition, the extreme case (together with the critical case and the revelatory case) is likely to involve only single-case studies [71], and for this reason the methodology adopted with the choice of IKCO' case study is particularly coherent.

The Iranian automotive industry, operating within a developing economy, has undergone to several changes in the market during the last three decades due to government decisions about the import replacement. As a consequence, the industry has experienced four distinct periods with different environmental situations [77]. First, as Koohi [77] explained, the industry started in Iran in 1966 with the establishment of IKCO, and, during the initial period from 1966 to 1979, it experienced no government support. During the second period, from 1979 to 1989, government provided the industry with the minimum support that it required for its existence while from 1989 to 1994 the government understand the strategic opportunities derived from this industry and started investments in this sector.

The fourth period, from 1994 to date, has been a period of growing awareness and of learning in which there was a strong support of government. The government policies have been addressed on protecting companies' market share in order to guarantee the industry with a quiet time range for capability development. Along with the Iranian Government policy of economic liberalization, the next period is expected to center on removing supports and leading the industry into free international competition. In fact, the industry is at the stage where it can start to compete using free-market mechanisms [78,79].

Accordingly, firms within the Iranian auto industry developed strategic capabilities during this latter period. Specifically, IKCO, as the leading company in the Iranian automotive industry, has been placed at the center of attention in regards to policy-making and has developed strategic capability. With over $60 \%$ of market share, the IKCO can be defined as the major car producer in the Iranian auto market. Their head office and the main production site are located in Tehran (Iran's capital city). IKCO started its activity in 1966 with an assembly activity of a car called 'Peykan', substantially based on an alliance with a British company. IKCO, established as a private company based on initial capital of US $\$ 40,000$, gradually localized the production of car parts, achieving self-sufficiency and increasing its production volume up to 98,000 sets of Peykan in 1977. After this date, the company turned into a public company under the control of the Iranian Government. Due to internal and external environmental turbulence, IKCO's growth trend experienced some fluctuations. However, the company continued the production of Peykan (without project changes) until 1988, when the Iran-Iraq War ended and the Iranian Government decided to restore the country after eight years of war that had imposed considerable economic damage, causing Iranian industries to fall behind the international edge of technology, marketing, and competition. Therefore IKCO started (in 1989) its 
three-year strategic alliance with Peugeot and developed a new Peykan—the "Peykageot"—-based on carrying over the engine from the Peugeot 504.

Furthermore, in 1994 the company set down a seven-year program to increase the volume of production up to 300,000 units and also improve the quality of the product toward international standards. In order to achieve these goals, the governance of IKCO has defined a gradually turnaround of internal organization. There were established department with specializations (e.g., research and development, engineering and production, strategic planning and studies, and marketing departments, etc.) and in the meantime, also subsidiary companies. Actually IKCO has six sites in different Iranian cities (Tabriz, Shiraz, Mashhad, Semnan, Tehran, and Babol) and other six sites around the world (Syria, Belarus, Venezuela, Egypt, Senegal, and Azerbaijan). This Iranian firms is now the leading car-maker in the Middle East, Central Asia, and North Africa. Its volume of production increased to 755,000 units in 2010, ranking it 14th in the world and positioning the Iranian automotive industry 16th in the world. Such capability development was based on the government's decision to support IKCO's capability development by enacting barriers to limit the entrance of foreign competitors within the period of capability development and to encourage the establishment and growth of a local supplier network (following what happened in Japan and South Korea). This support was dynamically implied throughout the 18-year period of capability development (beginning in 1994) and it enabled IKCO to develop value creation and capture processes in the face of global changes and trends in the automotive industry. Finally, in 2017, IKCO signed a strategic openness agreement (70 mL $€$, duration 36 months) with the Italian "Pininfarina" finalized to build a turnkey modular platform trough where IKCO will realize four models that can be replaced that are actually in commerce. IKCO will benefit from the engineeneristic study of the platform, the physic and virtual validation of the production, and the Italian style.

This description helps to understand how policy changes help national business by introducing tariffs on importing cars, and how much; from this, it is possible to think about how much innovation results from introducing barriers in the market competition.

In our case study, we chose IKCO's major product innovation projects (carried out during the 18 years of capability development when the company established its value creation and capture processes) as the unit of observation, allowing for us to study the product innovation projects that contributed to establishing value creation and capture processes as they unfolded, rather than prejudging which actors, technologies, and events might be central [80]. Interestingly, the pilot study revealed that IKCO's capability development occurred over the course of four major product innovation projects: the Pars, Samand, Soren, and Dena projects. This point not only made this case more relevant to the study's research question, but it also encouraged an embedded case design [70] to obtain granularity of operational detail, as well as variation for analytical comparisons [81]. This was particularly useful for tracking the unfolding of the four projects, each of which represented varied parts of the establishment of value creation and capture processes. The following Figure 1 the figure details the individual projects and the years in which they were individually made; moreover, it is possible to determine the temporal scope of interest that starts from 1994 to 2012. Each of these four projects has characteristics that match with the archetype product innovation projects suggested by Sanchez and Mahoney [82].

Based on the project data collected, we were able to report the story [83] of how dynamic governance methods formed, and open innovation and value creation and value capture processes emerged across the four projects. Three of the projects were past projects of the company and the fourth one was ongoing at the time of this study. This allowed for a combination of retrospective and real-time data to enhance our understanding of the sequence and flow of events [73,84]. Retrospective data clarify broad trends and the breadth of events, while real-time data are richer and more fine-grained, enhancing the depth of understanding of how events evolve over time [69]. 


\begin{tabular}{|c|c|}
\hline $\begin{array}{c}\text { Pars project } \\
(1994-1997)\end{array}$ & $\begin{array}{c}\text { Samand project } \\
(1996-2001) \\
\text { Incremental innovation }\end{array}$ \\
\hline Soren project & Modular innovation \\
(2005-2008) & Dena project \\
Architectural innovation & (2010-2012) \\
\hline
\end{tabular}

Figure 1. Matches between the case projects and the classification suggested by [82].

\subsection{Data Collection}

We used semi-structured interviews as the primary source of information in conjunction with our secondary sources of information that have been extracted from company websites, annual reports, newsletters and news from websites, other related websites, and the company archive. Before starting the mainstream data collection, we conducted a pilot including six interviews to build a bridge between theory and the specific practical context of the case company and industry [85]. While conducting the pilot interviews, published research around the same topic and/or industry, as well as secondary sources were reviewed to find the right terminology to indirectly investigate the study's constructs. The informants were IKCO employees from various departments who had the relevant educational background and insights about the company and its projects, and were also performing similar research in their current positions. In addition to establishing an accepted record of the events of the open innovation processes, and also the boundary scope of each case [72], the pilot interviews guided us in locating the most influential informants with regards to each case project as well as the case company's open innovation processes.

To further ensure that the sample included the most appropriate informants, we used snowball sampling [86] to find other individuals who were actively involved, influential, and insightful in each case project from varying parts of the company. The initial entry was typically made through project managers or other individuals in managerial positions. We interviewed multiple senior-level informants in relation to each case project to lessen the subject biases $[87,88]$. Some of the reports by interviewees were retrospective [88], while others were contemporary.

As indicated in Table 1, interviewees were drawn from multiple functional areas (e.g., R\&D, marketing, manufacturing) and from various organizational levels. Interviewees had at least six years of experience in the case company. Some were involved with a particular project while others had participated in different projects. According to their information and the stage of data collection interviewees were asked about one or more projects. During the 22 on site meetings (four-week period), a number of 37 interviews were conducted. IKCO's training and strategic department assisted in arranging the mutually convenient scheduling of interviews for the researchers and interviewees. The next wave of data collection included nine interviews that occurred one year after the primary wave of data collection. The second round of interviews mostly had a confirmatory nature.

Table 1. Sample of interviewees.

\begin{tabular}{lcc}
\hline \multirow{2}{*}{ Informants' Locations } & \multicolumn{2}{c}{ Number of Interviewees } \\
\cline { 2 - 3 } & 22 & Fecond Round \\
\hline NPD (New Product Development) department & 5 & 3 \\
Strategic planning and studies department & 4 & 2 \\
Production engineering department & 1 & 1 \\
Quality control department & 5 & - \\
Informants from SAPCO * & 3 \\
\hline
\end{tabular}

* SAPCO is IKCO's supply chain managing company which operates as part of the mother company and is closely involved in product innovation projects from strategic planning to implementation. 
Interviews commonly lasted from $60 \mathrm{~min}$ to two hours and they were conducted in the Persian language because using Persian meant a larger pool of informants to choose from. Furthermore, using English to conduct the interviews could have impeded clear communication and the accurate transfer of meanings, ideas, insights, and experiences from participants to the researchers. The interviews were recorded and then transcribed verbatim, generating about 700 pages of transcripts. The interview transcripts were then translated by the first author of this study from Persian to English. To achieve greater accuracy the translation was then double-checked by another Persian researcher (the second author).

Interviews included open-ended questioning that gave informants a larger scope to relay the chronology as they preferred. Also, specific request was made to the informants to provide more information and details if the descriptive answers were short and/or when new narrative strands were created. a specific. During all interviews, we asked informants to enrich their statements with practical examples or references to events occurred in specific projects; this to reduce problems of misunderstanding. According to [89] the data collection stopped when theoretical saturation was reached; that is, when additional data resulted in minimal incremental understanding [90]. We took several steps to mitigate potential informant biases [91], including retrospective bias. First, as noted above, we used open-ended questioning, which helped to obtain higher accuracy in retrospective reports $[88,92]$. Second, multiple informants were interviewed for each project from multiple parts of the hierarchy and from different divisions and functions (departments), representing different interests and perspectives. No significant contradictory evidence between their descriptions of events was found [93]. Third, we planned to interview highly influential, experienced, and knowledgeable informants who were most reliable, particularly in recalling important events [93-95]. Fourth, we maintained interview techniques, such as "courtroom questioning", "event tracking", and "nondirective questioning" [92,96], to gain more accurate information from the interviewees. Fifth, we promised anonymity to interviewees to encourage candor. Sixth, as mentioned earlier, we complemented the interview data with secondary sources of information for the purpose of triangulation $[96,97]$. Finally, informants were motivated to give accurate answers in order to help accelerate the company's path to openness and to develop open innovation processes [88].

\subsection{Data Analysis}

The data analysis comprised both planned and emergent parts. In general, the analytic process approach was aligned with the basic underlying philosophies of the extended case method [76], which is particularly helpful when using empirical data gathered through case studies to reconceptualize and extend theory. In contrast to grounded theory, this method attempts to consolidate concepts already produced by employing the empirical data to fill in the gaps and flaws in the relevant literature, elaborate their meaning and extend their coverage [98]. In accordance with this method, the study process of this research contained frequent moving back and forth between data analysis and literature, and, on some occasions, between data analysis and data collection. During the iteration between the data and literature, we looked at the case company and the selected projects to find evidence of the dynamics in governance approaches, the establishment of value creation and capture processes, and the emergence of open innovation; simultaneously, we sought existing theories and concepts to structure our analysis. Conversely, as interviews progressed, in order to refine and facilitate the elaboration of the themes emerged from the analysis of earlier interviews as well as to check the factual data, we decided to ask questions more we tended to turn toward more specific questions to refine and elaborate themes that emerged and to check factual data. Although the analysis process was highly iterative (particularly between data and literature), four different phases of analysis with distinct analytic characteristics were identifiable. 


\subsubsection{Phase One}

This stage included open coding of interview transcripts and the relevant organizational documents. For this purpose, we carefully read the transcripts and relevant documents to find themes and patterns [99]. During multiple reviewing of the available data, and along with the progression in our understanding from the phenomenon of research in the context of the study, we continuously located and highlighted the critical passages and generated memos [88,89]. By collecting, reviewing, and relabeling our interpretation and codes we fine-tuned memos [100] such that they could be grouped as conceptual clusters [101]. The resulting conceptual clusters could both address the data and point to the literature and are elaborated more in the next phase of analysis.

\subsubsection{Phase Two}

Once the initial categories emerged from the data, in the second round of coding we followed an abductive mode of analysis by travelling between the data and literature. In relation to the clusters that emerged from the data, we looked at the extant literature on governance and open innovation processes (in particular, knowledge exploration and exploitation) to see how the evidence found in the first round of coding could be related to the existing categories or possibly add to them. We therefore tried to use existing operationalizations and definitions to describe what had happened at IKCO using governance theories. Although details of our empirics revealed that our evidence tended to disclose alternative, and probably more coherent, measures of open innovation processes all data fell into existing categories within the governance and open innovation literature. Such coupling of the initial and second rounds of coding is quite similar to the multi-layer approach that was taken by Gioia et al. [102], in using firstand second-order codes to help delineate themes and aggregate dimensions through the examination and comparison of key events, as well as ideas that were discussed by informants. In accordance with this approach, following our first round of open coding (first-order coding), we engaged in axial coding [91], wherein we searched for relationships between and among the emergent clusters, which facilitated assembling them into higher-order themes. Finally, we gathered similar themes into several overarching concepts of governance approaches, forming the foundation of the emerging processes. Figure 2 illustrates this process and shows how we used this approach to link the measures of the dynamics of governance approaches to the evidence from the data.

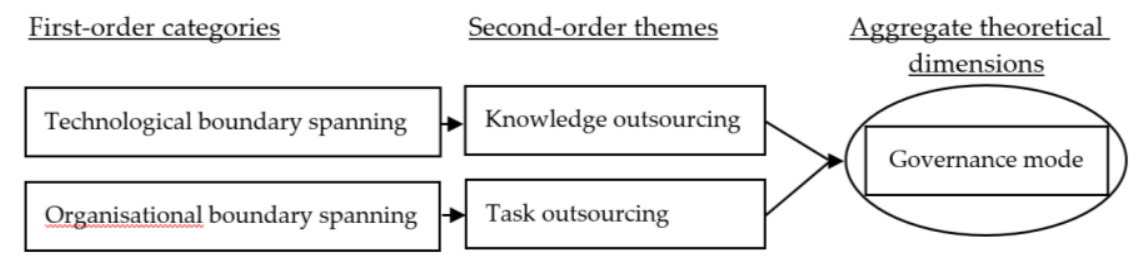

Figure 2. Data structure.

\subsubsection{Phase Three}

At this stage, we associated the dynamics in governance forms across different case projects with the emergence of value creation and capture processes, and the emergence of four levels of product architecture (architecture, subsystem, component, and part) of the case company. Table 2 summarizes the findings across the different product innovation projects. 
Table 2. Summary of coding and findings.

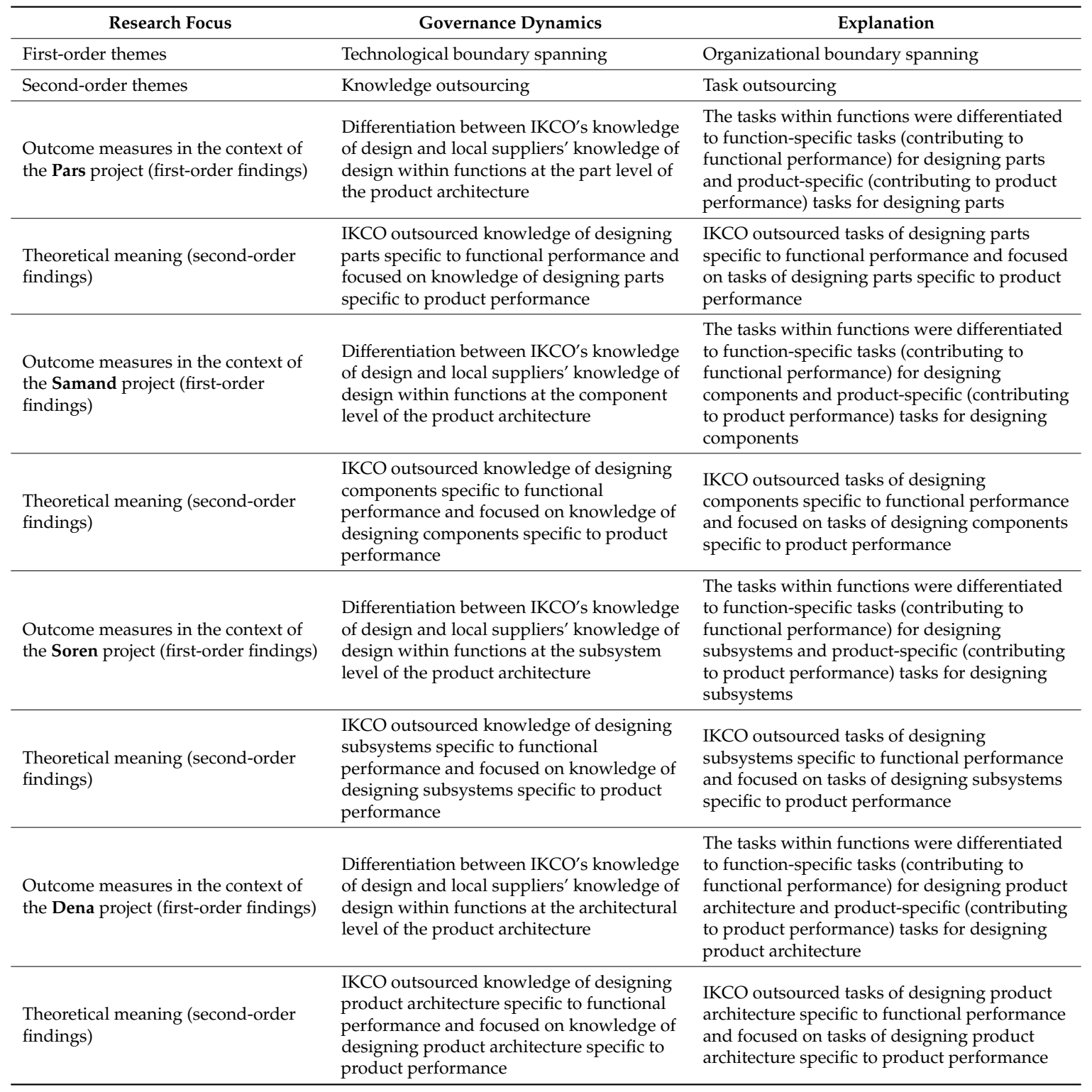

\section{Dynamics of Governance Approaches Across Different Product Innovation Projects}

The findings of this study illustrate the dynamics of governance approaches across the four product innovation projects. Litchenthaler and Litchenthaler [35] argued that knowledge creation and capture processes in firms are formed based on the firm's intention towards the exploration/exploitation of internal/external knowledge. In this regard, two issues of "knowledge outsourcing" and "task outsourcing" emerged as key themes during phase two of the data analysis investigating the dynamics of governance approaches, especially in terms of technological and organizational boundary spanning between firms (see Table 1). Here, knowledge outsourcing refers to opening up R\&D processes and using external knowledge to explore how IKCO's knowledge base is useful for designing new products. On the other hand, task outsourcing addresses IKCO's capacity to exploit new knowledge by managing outside capabilities (of local suppliers) to produce the parts and deliver the product (to realize the design that is gained from knowledge exploration). In this regard, some of the data collected and analyzed for each project are presented separately. 


\subsection{Pars Project}

\subsubsection{Knowledge Outsourcing}

In the Pars project, Peugeot had the locus of control. As such, IKCO undertook technology boundary spanning towards local suppliers concerning part design knowledge, which was related to functional performance, as mentioned by one participant:

"When we wanted to copy the car door tapes in Pars from Peugeot 405 and make them internally, we asked a foreign partner to tell us what technologies and equipment are needed for local suppliers to make it. Then, the suppliers equipped themselves with the technology and asked the foreign partner to help them to make the part".

In brief, during the Pars project, knowledge development at IKCO was confined to part engineering and the company outsourced part production knowledge to local suppliers.

\subsubsection{Task Outsourcing}

During the Pars project, IKCO initially had no knowledge; Peugeot was the only knowledge source at the top of the hierarchy, with IKCO receiving knowledge based on predetermined plans and schedules. Even at the lower levels of the product architecture, IKCO had no knowledge and it simply relied on Peugeot to handle the design tasks, as illustrated in the following statement:

"Peugeot gave us the documents regarding the detailed designs and we just released them in the organization to the related departments and areas".

This situation pushed IKCO to undertake organizational boundary spanning. In this regard, during the Pars project within IKCO's functions, some tasks in relation to the overall product performance were managed through a hierarchy of authority, with IKCO/Peugeot at the top. However, the design tasks related to the internal operation of parts were outsourced to suppliers and were managed by staff within IKCO's functions.

\subsection{Samand Project}

\subsubsection{Knowledge Outsourcing}

In the Samand project, IKCO undertook technology boundary spanning towards local suppliers with regards to the knowledge of designing components that are related to functional performance. Based on such technology boundary spanning, IKCO had to outsource knowledge of designing components specific to its functions to local suppliers, as one participant stated:

"Suppliers knew nothing of designing a car. They were just manufacturers and could just give advice on how to make bumpers or etc. They were just waiting for us to give them directions to follow. But now the situation has turned and we are following them".

In fact, during the Samand project, IKCO retained product-specific knowledge of component design within its organization and outsourced function-specific knowledge of component design to its local suppliers.

\subsubsection{Task Outsourcing}

In the Samand project, some tasks within functions needed to be managed based on a hierarchy of authority, because at that level, the functional tasks of design could be linked to the product performance. The role of the foreign partner, who was employed by top-level management, was to control design tasks in functions. However, in this project, IKCO undertook organizational boundary spanning by relying on its local suppliers to perform function-related tasks for designing components. As one interviewee explained: 
"In Samand, we asked for a foreign partner to design car door tapes based on our criteria and get involved with a local supplier for production and also transfer knowledge to them. The local supplier was involved with the foreign partner and during the later interactions for some amendments and modification in car door tapes, they matured in designing car door tapes and were directly connected to the foreign partner and we didn't have to deal with the foreign partner anymore and we arranged our requests through local suppliers".

Overall, during the Samand project IKCO outsourced function-related tasks for designing components to local suppliers and focused on product-specific tasks for designing components within its functions.

\subsection{Soren Project}

\subsubsection{Knowledge Outsourcing}

In the Soren project, while IKCO was developing subsystem knowledge in relation to the whole product performance, it performed technology boundary spanning towards local suppliers for subsystem knowledge that is related to functional performance. On this matter, one participant noted:

"In Soren, we defined the product and, for example, we need this specific light with these specifications or I want to carry over the lights from Samand; or, I need this specific form of bumper and this template-maker cannot perform the task and I will select the other one which is also appropriate in terms of my payment plan. I will also select the supplier to supply the part".

Similarly, another interviewee mentioned: “...product design will never migrate from IKCO, what migrates is detail design".

Indeed, the technology boundary spanning included outsourcing subsystem knowledge specific to functions to local suppliers and retaining subsystem knowledge, which was product-specific within IKCO.

\subsubsection{Task Outsourcing}

During the Soren project, while IKCO was performing subsystem-level tasks that were related to the overall design of the whole product, it undertook organizational boundary spanning toward its local suppliers concerning some functional-related tasks. In this project, as one participant commented, IKCO kept tasks specific to the whole product within its functions: "The engineers within functions knew more about the technology; however, IKCO knew what was needed, so functional people had to come to an agreement with the project manager on a design which suited both of them".

In fact, during the Soren project IKCO outsourced function-specific tasks for designing subsystems to local suppliers and focused on product-specific tasks for designing subsystems within its functions.

\subsection{Dena Project}

\subsubsection{Knowledge Outsourcing}

In the Dena project, while IKCO was developing architectural-level knowledge in relation to the whole product performance, it undertook technology boundary spanning towards its local suppliers for the architectural knowledge concerning the function's performance. As one interviewee explained:

"We shared our market needs with our local suppliers and they followed them up to fulfill them. In fact, we did target setting based on benchmarking of our competitors and determined our expectations at the system level, and the local suppliers designed and implemented a system which covered our requirements". 
However, through such boundary spanning in knowledge specific to functions, IKCO focused on developing architectural knowledge, which contributed to the whole product performance, as noted by one participant:

"We told our suppliers that this is our style for the car and these are the parts nearby. We also mentioned our limitations as well as obligations; for example, we have to have a certain lamp and the total usage of electricity should not exceed this amount. Then, the local supplier had its own comments as well. For example, the local suppliers pointed to its limitation regarding the capacity of injection molding equipment, which was up to $60 \mathrm{~g}$ and could not produce such lights with these specifications. The local supplier asked us to change the designs so that it could produce the part with its current machinery. If we couldn't fit our requirements with the existing capacity of the local supplier, it was obliged to think about new machinery like an injection molding machine with a capacity of $1200 \mathrm{~g}$ ".

Overall, during this project, IKCO developed product-specific architectural knowledge within its functions and outsourced function-specific architectural knowledge to its local suppliers.

\subsubsection{Task Outsourcing}

During the Dena project, while IKCO was performing tasks for designing product architecture related to the whole product performance, it undertook organizational boundary spanning in relation to designing tasks that are related to functional performance at this level to local suppliers. As one interviewee described:

"Windshield wipers have two options of having either one blade or two blades and they have to clear a specific surface. Before, we did the design here and did the simulations here. However, during Soren, the local suppliers were enabled to deliver our desired functions through contacting and asking a foreign source about the required functions ... But during Dena, they did not need the foreign partner anymore and could do the designs by themselves and we did not do the design anymore and we just gave them the specifications. They gave us ideas about new technologies and submitted proposals for new systems like the intelligent windshield wiper. They told us that the whole system of windshield wiper that we had was outdated and they had transferred a new technology that could improve the performance and was also cost efficient. So, we passed the design responsibility to them".

In fact, during the Dena project IKCO outsourced function-related tasks for designing the product architecture to local suppliers and kept function-specific tasks within its functions.

Overall, findings of this study relating to task outsourcing across case projects indicate that, within each product innovation project studied, IKCO outsourced function-related tasks for designing at a certain level to local suppliers, which led to differentiation between function-specific tasks and product-specific tasks for designing at that level within IKCO's functions. Since differentiation between tasks within functions at any level leads to differentiation among functions at that level, it can be concluded that across different product innovation projects IKCO's functions were differentiated at different levels of the product architecture.

\section{Emergence of Value Creation and Capture Processes Across Different Levels of the Product Architecture}

This study reveals the processes that are associated with the dynamics of governance modes and the emergence of value creation and capture processes across the case study treated using a multi-project approach. The study findings reveal that IKCO gradually outsourced knowledge and capability to its local suppliers across different levels of the product architecture. Firstly, the single case study with multi-projects approach provide empirical evidence demonstrating that, within each project, IKCO outsourced knowledge of design related to functional performance to local suppliers. 
More specifically, within the Pars project IKCO outsourced part design knowledge (which was related to functional performance) to local suppliers and focused on part design knowledge, which was related to product performance. Similarly, across the other projects IKCO outsourced components knowledge (Samand), subsystems knowledge (Soren), and architectural knowledge (Dena) specific to functions and focused on product-specific knowledge of design at those levels. Overall, across the four product innovation projects, IKCO gradually opened up its R\&D activities enabling value creation at different levels of the product architecture from the part level to the architectural level (following a bottom-up pattern).

Secondly, the findings from the single case study with multi-projects approach show a differentiation between design tasks within each product innovation project based on the dynamics in the agency that is responsible for performing those tasks. More specifically, within the Pars project, the tasks related to the whole product performance were managed through the hierarchy of authority in IKCO and tasks related to functional performance were outsourced to local suppliers. Similarly, within the later projects the same occurred in regards to designing components (in the Samand project), subsystems (in the Soren project), and the product architecture (in the Dena project), where IKCO focused on product-specific tasks (managed through the hierarchy) and outsourced function-specific tasks to local suppliers. Accordingly, across the case projects, step-by-step IKCO opened up its production tasks, enabling it to develop value capture processes from the part level up to the architectural level of the product architecture.

Taken together, as Figure 3 illustrates, we can recognize a bottom-up pattern in establishing value creation and capture processes across different product innovation projects and from the part level to the component, subsystem, and architectural levels of the product architecture. IKCO has, step-by-step, outsourced knowledge and capability to its local suppliers. Such emerging patterns from the part level to the architectural level form a mechanism, which reveals the emergence of value creation and value capture processes across different levels of the product architecture over time, contributing to the unfolding of coupled open innovation at each level of the product architecture. Such a mechanism is consistent with what Pettigrew [68] referred to as generative mechanisms, defined as the underlying mechanism of micro-processes that contribute to the emergence of organizational-level outcomes. Aligned with such a conceptualization, the emergent patterns of this study reveal the process-and project-level dynamics through which the content of coupled open innovation has emerged.

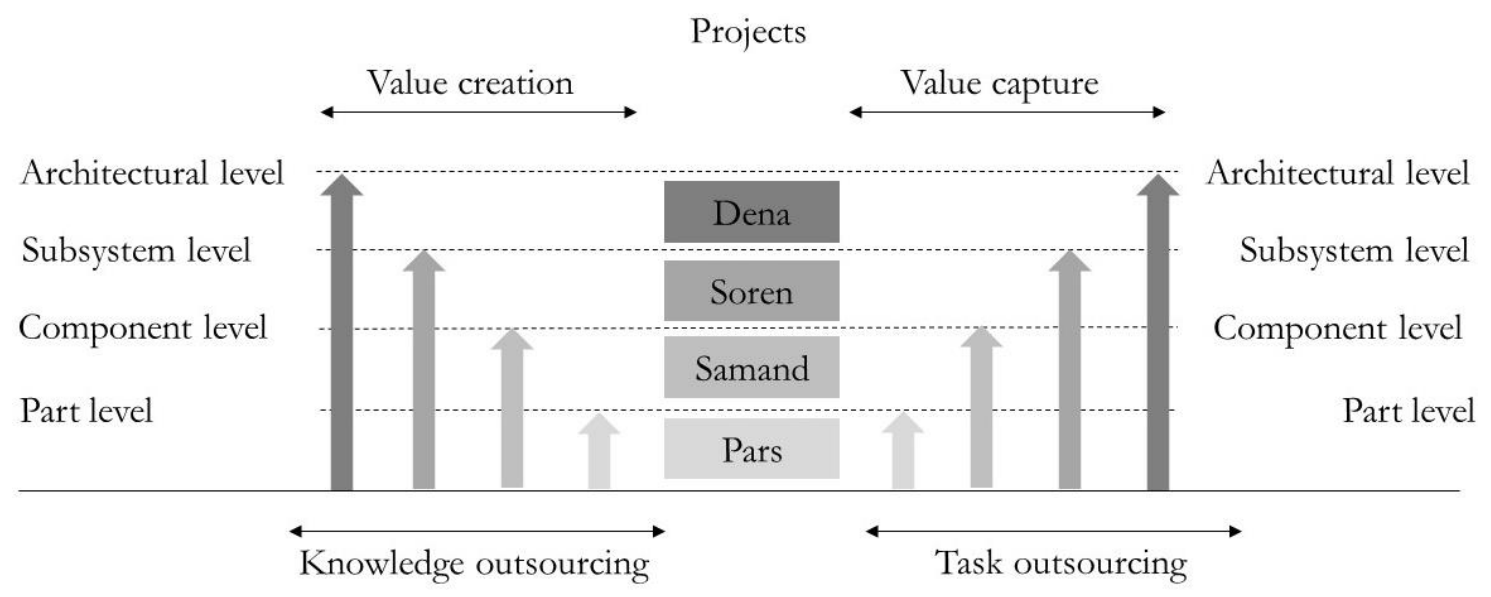

Figure 3. Dynamics in establishing value creation and value capture processes at Iran Khodro Company (IKCO) across different product innovation projects and different levels of the product architecture.

The findings suggest that IKCO has achieved coupled open innovation gradually and from the part level up to the architectural level and across a series of product innovation projects, leading to the gradual emergence of value creation and capture processes at different levels of the product architecture. Under a cause-effect perspective, the results that are noted and synthesized in this section 
derive from decisions taken by governance oriented to create value. Therefore, the sum of the value created in the single project through these policies has had a significant impact on the economic sustainability of the IKCO, ensuring a greater viability of the firm overtime.

\section{Conclusions and Future Research}

In responding to the current concerns around the concept of open innovation, the needs to bring value creation and value capture processes and considering the economic sustainability is becoming more and more vital. In this regard, we may accommodate the concept of "openness" by reframing the existing theories to better account for some of the flaws in the current theoretical structure. However, we need to further understand the process behind coupled open innovation to be able to support the successful emergence of these processes within firms. For this purpose, we propose to integrate governance theories with the capability-based view to provide a complete picture of such processes. Aligned with this view, this study was designed to examine how coupled open innovation processes emerge out of capability development within companies. In particular, we focused on the dynamics of governance and studied how value creation and value capture processes emerged at IKCO across different levels of the product architecture. Therefore, we investigated how different product innovation projects could encompass the unfolding of coupled open innovation processes. Based on this approach, we studied the single case of IKCO and investigated it using a multi-project approach in order to understand how open innovation processes have emerged in this company across different product innovation projects.

The findings of this research contribute to the field of open innovation by uncovering the process behind the emergence of value creation and value capture processes in the context of coupled open innovation. In this regard, this study reveals the generative mechanism underlying the establishment of value creation and capture processes for a sustainable business. In particular, this research shows that, along with dynamics in governance approaches across the four product innovation projects and from the part level to the architectural level of the product architecture, value creation and value capture processes have been established, step-by-step, at the same levels of the product architecture. We found that such dynamics in governance across different levels of the product architecture underlying value creation processes include the step-by-step outsourcing of knowledge to local suppliers from the part to architectural level. Moreover, we found that similar dynamics in outsourcing capability to local suppliers exist, where IKCO, step-by-step, outsourced its capability to its local suppliers from the part to architectural level of the product architecture and across different product innovation projects. As a result, coupled open innovation processes have unfolded over time at different levels of the product architecture and across a series of product innovation projects. Finally, the process of value creation and value capture can impact on the sustainability of the business contributing in the search for viability in the international competitive environment.

These findings may help us to develop a conceptualization of how openness can be achieved incrementally by establishing value creation and capture processes, from the part to architectural level of the product architecture, within a series of product innovation projects and from this to reach more sustainable business. Academically, such a conceptualization can be verified across different contexts (such as different industries, economies, regions, etc.) and used to develop testable hypotheses. Practically, this conceptualization may help managers to develop a step-by-step framework that can guide them in managing their company's product innovation projects dynamically to make sure that, over time, they establish effective coupled open innovation processes.

The results of this paper also contribute to better understanding the link between open innovation and economic sustainability by addressing the importance of the degree of openness in relation to four different levels of the product architecture (Figure 3) that were obtained from the analysis of the qualitative data.

The first level is the "part level" and it involves suppliers that do not possess internal knowledge and requires a third parties to guide them. 
The second level is the "component level", where the suppliers possess a general knowledge but require a specific mentorship to learn the specific skills to complete the necessary tasks.

The third one is the "subsystem level" which involve those suppliers that possess high level of knowledge in dealing with component modularity and optimizing customer requirements.

Last but not least is the "architectural level", which involves all those suppliers that have the knowledge to provide to their customers with more radical innovative solutions.

The four levels product architecture require a unique mix between knowledge outsourcing and task outsourcing generating different levels of value creation and value capture. Managing this complex process can lead to ongoing business success and finally to an economic sustainable model.

Based on the unique results of this study, it is possible to suggest that economic sustainability cannot be achieve simply by outsourcing at the architectural level everything. Therefore, an organization has to assess its external and internal capabilities and the modularity and sensibility of their products in order to choose the best sustainable options for their open innovation strategy with their suppliers, while considering economic sustainability as the way to ensure the profitability not only for today, but also for tomorrow. According to the current literature, the radical innovation (usually realized through project management) is normally related to the risky business [103] or high risk [104], high uncertainty projects [105]. Therefore, the existence of the multiple levels in the open innovation can also help to improve the risks awareness, and from this contribute to improving risk assess and mitigation to achieve the expected results from the innovation practices.

Another important outcome of this paper can be discussed under the Schumpeterian linear perspective and especially due to the introduction of an entrepreneurial view about allowing external innovators $[15,16,20]$. This case study seems to support the so-called Schumpeter Mark 1 perspective, which promotes the process of engaging external parties to widening the innovators at the disposal of large firms to gain a competitive advantage [16]. Future research can be oriented to understand whether the results achieved in this paper can be cross validated with case studies from other countries in the same or close sector. The concept of economic sustainability should be further investigated and compared against the three types of open innovation (inbound, outbound, and coupled of open innovation). The last point for future research to investigate this very important topic from a quantitative approach in order to confirm the major findings of this paper, including the four levels of product architecture, the relationship between the degree of openness, the needs of knowledge and task outsourcing, and the possible impact of the four levels on the innovative project risks.

Author Contributions: Although the paper is the result of synergic work, Sections 3 and 4 are attributed to A.J.K.; Section 5 is attributed to K.M.; Section 2 is attributed to M.P.; Sections 1-6 are attributed to G.L.C.

Funding: This research received no external funding.

Conflicts of Interest: The authors declare no conflict of interest.

\section{References}

1. Chesbrough, H.W.; Appleyard, M.M. Open Innovation and Strategy. Calif. Manag. Rev. 2007, 50, 57-76. [CrossRef]

2. Lengnick-Hall, C.A. Innovation and Competitive Advantage: What We Know and What We Need to Learn. J. Manag. 1992, 18, 399-429. [CrossRef]

3. Rupo, D.; Perano, M.; Centorrino, G.; Vargas Sanchez, A. A Framework Based on Sustainability, Open Innovation, and Value Cocreation Paradigms-A Case in an Italian Maritime Cluster. Sustainability 2018, 10, 729. [CrossRef]

4. $\quad$ Elkington, J. Cannibals with Forks - The Triple Bottom Line of 21st Century Business; Capstone Publishing Ltd.: Oxford, UK, 1999; ISBN 978-1-841-12084-3.

5. Lopes, C.M.; Scavarda, A.; Hofmeister, L.F.; Tavares Thomé, A.M.; Roehe Vaccaro, G.L. An analysis of the interplay between organizational sustainability, knowledge management, and open innovation. J. Clean. Prod. 2017, 142, 476-488. [CrossRef] 
6. Dyllick, T.; Hockerts, K. Beyond the business case for corporate sustainability. Bus. Strateg. Environ. 2002, 11, 130-141. [CrossRef]

7. Moreno-Gené, J.; Sánchez-Pulido, L.; Cristobal-Fransi, E.; Daries, N. The Economic Sustainability of Snow Tourism: The Case of Ski Resorts in Austria, France, and Italy. Sustainability 2018, 10, 3012. [CrossRef]

8. Bansal, P.; DesJardine, M. Business sustainability: It is about time. Strateg. Org. 2014, 12, 70-78. [CrossRef]

9. Sisodiya, S.R.; Johnson, J.L.; Grégoire, Y. Inbound open innovation for enhanced performance: Enablers and opportunities. Ind. Mark. Manag. 2013, 5, 836-849. [CrossRef]

10. Leonard-Barton, D. Wellsprings of Knowledge; Harvard Business School Press: Cambridge, MA, USA, 1995.

11. Calantone, R.; Cavusgil, S.T.; Zhao, Y. Learning orientation, firm innovation capability, and firm performance. Ind. Mark. Manag. 2002, 6, 151-524. [CrossRef]

12. Tellis, G.J. Important research questions in technology and innovation. Ind. Mark. Manag. 2008, 6, 629-632. [CrossRef]

13. Porter, M.E. Competitive Strategy; Free Press: New York, NY, USA, 1980.

14. Gassmann, O.; Enkel, E.; Chesbrough, H. The future of open innovation. R D Manag. 2010, 40, $213-221$. [CrossRef]

15. Schumpeter, J.A. The Theory of Economic Development: An Inquiry into Profits, Capital, Credit, Interest, and the Business Cycle; Transaction Publishers: Piscataway, NJ, USA, 1934; Volume 55.

16. Yun, J.J.; Won, D.; Park, K. Entrepreneurial cyclical dynamics of open innovation. J. Evol. Econ. 2018, 1-24. [CrossRef]

17. Teece, D.J.; Pisano, G. The dynamic capabilities of firms: An introduction. Ind. Corp. Chang. 1994, 3, 537-556. [CrossRef]

18. Eisenhardt, K.M.; Martin, J.A. Dynamic Capabilities: What Are They? Strateg. Manag. J. 2000, 21, $1105-1121$. [CrossRef]

19. Teece, D.J.; Pisano, G.; Shuen, A. Dynamic capabilities and strategic management. Strateg. Manag. J. 1997, 18, 509-553. [CrossRef]

20. Yun, J.J. How do we conquer the growth limits of capitalism? Schumpeterian dynamics of open innovation. J. Open Innov. Technol. Mark. Complex. 2015, 1, 17. [CrossRef]

21. Chesbrough, H. The logic of open innovation: Managing intellectual property. Calif. Manag. Rev. 2003, 45, 33-58. [CrossRef]

22. Hirschman, A. Exit, Voice and Loyalty: Responses to Decline in Firms, Organizations, and States; Original Work Published 1970; Harvard University Press: Cambridge, MA, USA, 1982.

23. Shane, S.A. A general Theory of Entrepreneurship: The Individual-Opportunity Nexus; Edward Elgar Publishing: Cheltenham, UK, 2003; ISBN 9781843763826.

24. Von Hippel, E.A. Democratizing Innovation; The MIT Press: Cambridge, MA, USA, 2005.

25. Gruber, M.; MacMillan, I.C.; Thompson, J.D. Look before you leap: Market opportunity identification in emerging technology firms. Manag. Sci. 2008, 54, 1652-1665. [CrossRef]

26. Jeppesen, L.B.; Lakhani, K.R. Marginality and problem-solving effectiveness in broadcast search. Org. Sci. 2010, 21, 1016-1033. [CrossRef]

27. Foss, N.J.; Laursen, K.; Pedersen, T. Linking customer interaction and innovation: The mediating role of new organizational practices. Org. Sci. 2011, 22, 980-999. [CrossRef]

28. Afuah, A.; Tucci, C.L. Crowdsourcing as a solution to distant search. Acad. Manag. Rev. 2012, 37, 355-375. [CrossRef]

29. Felin, T.; Zenger, T.R. Closed or open innovation? Problem solving and the governance choice. Res. Policy 2014, 43, 914-925. [CrossRef]

30. West, J.; Salter, A.; Vanhaverbeke, W.; Chesbrough, H. Open innovation: The next decade. Res. Policy 2014, 43, 805-811. [CrossRef]

31. Gambardella, A.; Panico, C. On the management of open innovation. Res. Policy 2014, 43, 903-913. [CrossRef]

32. Teece, D.J. Explicating dynamic capabilities: The nature and microfoundations of (sustainable) enterprise performance. Strateg. Manag. J. 2007, 28, 1319-1350. [CrossRef]

33. Spithoven, A.; Clarysse, B.; Knockaert, M. Building absorptive capacity to organise inbound open innovation in traditional industries. Technovation 2011, 31, 10-21. [CrossRef]

34. West, J.; Bogers, M. Leveraging external sources of innovation: A review of research on open innovation. J. Prod. Innov. Manag. 2014, 31, 814-831. [CrossRef] 
35. Lichtenthaler, U.; Lichtenthaler, E. A capability-based framework for open innovation: Complementing absorptive capacity. J. Manag. Stud. 2009, 46, 1315-1338. [CrossRef]

36. Lichtenthaler, U. Is open innovation a field of study or a communication barrier to theory development? A contribution to the current debate. Technovation 2011, 31, 138-139. [CrossRef]

37. Gassmann, O.; Enkel, E. Towards a theory of open innovation: Three core process archetypes. In Proceedings of the R\&D Management Conference (RADMA), Lisbon, Portugal, 6-9 July 2004; pp. 1-18.

38. Henkel, J. Champions of revealing-The role of open source developers in commercial firms. Ind. Corp. Chang. 2009, 18, 435-471. [CrossRef]

39. Chiaroni, D.; Chiesa, V.; Frattini, F. Unravelling the process from closed to open innovation: Evidence from mature, asset-intensive industries. $R$ D Manag. 2010, 40, 222-245. [CrossRef]

40. Chiaroni, D.; Chiesa, V.; Frattini, F.; Terruzzi, R. Implementing open innovation: A case study in the renewable energy industry. Int. J. Technol. Intell. Plan. 2015, 10, 195-221. [CrossRef]

41. Lewin, K. Frontiers in group dynamics II. Channels of group life; social planning and action research. Hum. Relat. 1947, 1, 143-153. [CrossRef]

42. Van de Ven, A.H. Suggestions for studying strategy process: A research note. Strateg. Manag. J. 1992, 13, 169-188. [CrossRef]

43. Huizingh, E.K. Open innovation: State of the art and future perspectives. Technovation 2011, 31, 2-9. [CrossRef]

44. Michelino, F.; Caputo, M.; Cammarano, A.; Lamberti, E. Inbound and Outbound Open Innovation: Organization and Performances. J. Technol. Manag. Innov. 2014, 9, 65-82. [CrossRef]

45. Chesbrough, H.W. Open Innovation: The New Imperative for Creating and Profiting from Technology; Harvard Business Press: Cambridge, MA, USA, 2006; ISBN 9781422102831.

46. Enkel, E.; Gassmann, O.; Chesbrough, H. Open R\&D and open innovation: Exploring the phenomenon. $R D$ Manag. 2009, 39, 311-316. [CrossRef]

47. Piller, F.; West, J. Firms, users, and innovation: An interactive model of coupled open innovation. In New Frontiers in Open Innovation; Chesbrough, H., Vanhaverbeke, W., West, J., Eds.; Oxford University Press: Oxford, UK, 2014; ISBN 9780199682461.

48. Harhoff, D.; Scherer, F.M.; Vopel, K. Citations, family size, opposition and the value of patent rights. Res. Policy 2003, 32, 1343-1363. [CrossRef]

49. Henkel, J.; von Hippel, E. Welfare implications of user innovation. J. Technol. Transf. 2005, 30, $73-87$. [CrossRef]

50. Von Krogh, G.; Von Hippel, E. The promise of research on open source software. Manag. Sci. 2006, 52, 975-983. [CrossRef]

51. Von Hippel, E. The sources of innovation. In Das Summa Summarum des Management; Boersch, C., Elschen, R., Eds.; Gabler Springer: Berlin/Heidelberg, Germany, 2007; ISBN 978-3-8349-0519-2.

52. Teece, D.J. Profiting from technological innovation: Implications for integration, collaboration, licensing and public policy. Res. Policy 1986, 15, 285-305. [CrossRef]

53. Teece, D.J. Reflections on "profiting from innovation". Res. Policy 2006, 35, 1131-1146. [CrossRef]

54. Winter, S.G. Toward a neo-Schumpeterian theory of the firm. Ind. Corp. Chang. 2006, 15, 125-141. [CrossRef]

55. Becker, M.C.; Zirpoli, F. Organizing new product development: Knowledge hollowing-out and knowledge integration-The FIAT auto case. Int. J. Oper. Prod. Manag. 2003, 23, 1033-1061. [CrossRef]

56. Christensen, R. Log-Linear Models and Logistic Regression, 2nd ed.; Springer Science \& Business Media: New York, NY, USA, 1997; ISBN 0-387-98247-7.

57. West, J. Does appropriability enable or retard open innovation. In Open Innovation: Researching a New Paradigm; Chesbrough, H., Vanhaverbeke, W., West, J., Eds.; Oxford University Press: Oxford, UK, 2006; pp. 109-133. ISBN 978-0199290727.

58. West, J.; Gallagher, S. Challenges of open innovation: The paradox of firm investment in open-source software. R D Manag. 2006, 36, 319-331. [CrossRef]

59. Dahlander, L.; Gann, D.M. How open is innovation? Res. Policy 2010, 39, 699-709. [CrossRef]

60. West, J.; Lakhani, K.R. Getting clear about communities in open innovation. Ind. Innov. 2008, 15, $223-231$. [CrossRef]

61. Fichter, K. Innovation communities: The role of networks of promotors in Open Innovation. $R$ D Manag. 2009, 39, 357-371. [CrossRef] 
62. Hagedoorn, J. Interorganizational modes of cooperation. Strateg. Manag. J. 1993, 14, 371-385. [CrossRef]

63. Hagedoorn, J. Inter-firm R\&D partnerships: An overview of major trends and patterns since 1960. Res. Policy 2002, 31, 477-492. [CrossRef]

64. Chesbrough, H.; Bogers, M. Explicating open innovation: Clarifying an emerging paradigm for understanding innovation. In New Frontiers in Open Innovation; Chesbrough, H., Vanhaverbeke, W., West, J., Eds.; Oxford University Press: Oxford, UK, 2014; pp. 3-28. ISBN 9780199682461.

65. Vanhaverbeke, W.; Chesbrough, H.; West, J. Surfing the new wave of open innovation research. In New Frontiers in Open Innovation; Chesbrough, H., Vanhaverbeke, W., West, J., Eds.; Oxford University Press: Oxford, UK, 2014; p. 281. ISBN 9780199682461.

66. Graebner, M.E.; Martin, J.A.; Roundy, P.T. Qualitative data: Cooking without a recipe. Strateg. Org. 2012, 10, 276-284. [CrossRef]

67. Feldman, M.S.; Orlikowski, W.J. Theorizing practice and practicing theory. Org. Sci. 2011, 22, $1240-1253$. [CrossRef]

68. Pettigrew, A.M. Longitudinal field research on change: Theory and practice. Org. Sci. 1990, 1, $267-292$. [CrossRef]

69. Langley, A. Strategies for theorizing from process data. Acad. Manag. Rev. 1999, 24, 691-710. [CrossRef]

70. Yin, R.K. Case Study Research: Design and Methods, 2th ed.; Sage Publications: Thousand Oaks, CA, USA, 1994; ISBN 0803956630.

71. Yin, R.K. Case Study Research and Applications: Design and Methods, 6th ed.; Sage Publications: Thousand Oaks, CA, USA, 2018; ISBN 9781506336769.

72. Yin, R.K. Case Study Research Design and Methods Applied Social Research Methods Series, 3th ed.; Sage Publications: Thousand Oaks, CA, USA, 2003; ISBN 0-7619-2552-X.

73. Pettigrew, A.M. The character and significance of strategy process research. Strateg. Manag. J. 1992, 13, 5-16. [CrossRef]

74. Buijs, M.J.; Van der Bol, N.; Teisman, G.R. Metropolitan regions as self-organizing systems. In Managing Complex Governance Systems; Teisman, G.R., Van Buuren, M.W., Gerrits, L.M., Eds.; Routledge: New York, NY, USA, 2009; pp. 97-115. ISBN 9780415459730.

75. Flood, R.L. Rethinking the Fifth Discipline: Learning within the Unknowable; Routledge: London, UK, 1999; ISBN 0415185300.

76. Burawoy, M. Ethnography Unbound: Power and Resistance in the Modern Metropolis; University of California Press: Berkeley, CA, USA, 1991; ISBN 9780520073227.

77. Koohi, I. Iran car industry policies. J. Appl. Sci. 2006, 6, 416-418. [CrossRef]

78. Abedini, J.; Péridy, N. The emergence of Iran in the world car industry: An estimation of its export potential. World Econ. 2009, 32, 790-818. [CrossRef]

79. Pakneiat, M.; Panahi, M.; Noori, J. Firm capabilities and diversification: How mission matters. Bus. Strat. Ser. 2010, 11, 248-260. [CrossRef]

80. Czarniawska, B. Narratives in Social Science Research; Sage Publications Ltd.: London, UK, 2004.

81. Bechky, B.A. Making organizational theory work: Institutions, occupations, and negotiated orders. Org. Sci. 2011, 22, 1157-1167. [CrossRef]

82. Sanchez, R.; Mahoney, J.T. Modularity, flexibility, and knowledge management in product and organization design. Strateg. Manag. J. 1996, 17, 63-76. [CrossRef]

83. Pratt, M.G. From the editors: For the lack of a boilerplate: Tips on writing up (and reviewing) qualitative research. Acad. Manag. J. 2009, 52, 856-862. [CrossRef]

84. Leonard-Barton, D. A dual methodology for case studies: Synergistic use of a longitudinal single site with replicated multiple sites. Org. Sci. 1990, 1, 248-266. [CrossRef]

85. Alreck, P.L.; Settle, R.B. The Survey Research Handbook; McGraw-Hill Irwin: Boston, MA, USA, 1995; ISBN 0-07-294548-6.

86. Patton, M.Q. Two decades of developments in qualitative inquiry a personal, experiential perspective. Qual. Soc. Work 2002, 1, 261-283. [CrossRef]

87. Golden, B.R. The past is the past-Or is it? The use of retrospective accounts as indicators of past strategy. Acad. Manag. J. 1992, 35, 848-860. [CrossRef]

88. Miller, C.C.; Cardinal, L.B.; Glick, W.H. Retrospective reports in organizational research: A reexamination of recent evidence. Acad. Manag. J. 1997, 40, 189-204. [CrossRef] 
89. Strauss, A.L. Qualitative Analysis for Social Scientists; Cambridge University Press: Cambridge, UK, 1987; ISBN 978-0521338066.

90. Lee, T.W. Using Qualitative Methods in Organizational Research; Sage Publications: Thousand Oaks, CA, USA, 1999; ISBN 0-7619-0806-4.

91. Gioia, D.A.; Corley, K.G.; Hamilton, A.L. Seeking qualitative rigor in inductive research. Notes on the Gioia methodology. Organ. Res. Meth. 2013, 16, 15-31. [CrossRef]

92. Lipton, M. Why Poor People Stay Poor: Urban Bias in World Development; Harvard University Press: Cambridge, MA, USA, 1977; ISBN 0708104134.

93. Seidler, J. On using informants: A technique for collecting quantitative data and controlling measurement error in organization analysis. Am. Sociol. Rev. 1974, 39, 816-831. [CrossRef]

94. Huber, G.P.; Power, D.J. Retrospective reports of strategic-level managers: Guidelines for increasing their accuracy. Strateg. Manag. J. 1985, 6, 171-180. [CrossRef]

95. Kumar, N.; Stern, L.W.; Anderson, J.C. Conducting interorganizational research using key informants. Acad. Manag. J. 1993, 36, 1633-1651. [CrossRef]

96. Ozcan, P.; Eisenhardt, K.M. Origin of alliance portfolios: Entrepreneurs, network strategies, and firm performance. Acad. Manag. J. 2009, 52, 246-279. [CrossRef]

97. Jick, T.D. Mixing qualitative and quantitative methods: Triangulation in action. Adm. Sci. Q. 1979, 24, 602-611. [CrossRef]

98. Danneels, E. The dynamics of product innovation and firm competences. Strateg. Manag. J. 2002, 23, 1095-1121. [CrossRef]

99. Miles, M.B.; Huberman, A.M. Qualitative Data Analysis: An Expanded Sourcebook; Sage Publications: Thousand Oaks, CA, USA, 1994; ISBN 9780803946538.

100. Eisenhardt, K.M. Building theories from case study research. Acad. Manag. Rev. 1989, 14, 532-550. [CrossRef]

101. Berg, B.L. Qualitative Research Methods for the Social Sciences; Allyn \& Bacon: Boston, MA, USA, 1989.

102. Gioia, D.A.; Thomas, J.B.; Clark, S.M.; Chittipeddi, K. Symbolism and strategic change in Academia: The Dynamics of Sensemaking and Influence. Organ. Sci. 1994, 5, 363-383. [CrossRef]

103. Keizer, J.A.; Halman, J.I.M. Diagnosing risk in radical innovation projects. Res. Technol. Manag. 2007, 5, 30-36. [CrossRef]

104. Treacy, M.; Innovation as a Last Resort. Harv. Bus. Rev. 2004, 29-30. Available online: https://hbr.org/2004/ 07 /innovation-as-a-last-resort (accessed on 21 October 2018).

105. O'Connor, G.C.; McDermott, C.M. The human side of radical innovation. J. Eng. Technol. Manag. 2004, 21, 11-30. [CrossRef]

(C) 2018 by the authors. Licensee MDPI, Basel, Switzerland. This article is an open access article distributed under the terms and conditions of the Creative Commons Attribution (CC BY) license (http://creativecommons.org/licenses/by/4.0/). 